równo treść, jak i forma książki (jasny, czytelny styl) są przystępne nie tylko dla historyka, historyka wychowania, pedagoga, czyli czytelnika - specjalisty, ale także dla studentów i wszystkich ,amatorów”, którzy interesują się historią szkolnictwa i omawianych regionów.

Katarzyna Kabacińska

\title{
Dorota Źołądź-Strzelczyk, Katarzyna Kabacińska (red.), Dawne zabawy dziecięce, Wydawnictwo DiG \& Muzeum Zabawek i Za- bawy w Kielcach, Kielce - Warszawa 2008, ss. 72.
}

W 2008 r., nakładem Wydawnictwa DiG oraz Muzeum Zabawy i Zabawek w Kielcach, ukazała się książka Dawne zabawy dziecięce pod redakcją Doroty Żołądź-Strzelczyk i Katarzyny Kabacińskiej. Publikacja ta jest wyrazem zainteresowań naukowych Redaktorek, których tematyka badawcza koncentruje się na dzieciństwie w dawnych czasach oraz, jak sam tytuł wskazuje, dawnych zabawach i zabawkach dziecięcych. Do współpracy Autorki zaprosiły Ryszarda Kantora oraz dyrektor Muzeum Zabawek i Zabawy w Kielcach - Jolantę Podsiadło, którzy to swoimi tekstami dotyczącymi problematyki zabawy, stworzyli swoiste jej podsumowanie.

Bazę źródłową publikacji stanowi dzieło Łukasza Gołębiowskiego Gry i zabawy różnych stanów w kraju całym, lub niektórych tylko prowincjach wydane w Warszawie w $1831 \mathrm{r}$. To z niego pochodzą opisy zabaw przedstawionych w książce, ale nie tylko. Opisy pochodzą również z dzieł Sebastiana Petrycego czy Jędrzeja Kitowicza, a także z utworów literackich oraz tekstów z czasopism XIX w., takich jak „Kronika Rodzinna” czy „Przyjaciel Dzieci”. Publikację tę wyróżniają jednak nie tylko szczegółowe opisy poszczególnych zabaw dziecięcych, lecz przede wszystkim obszerna baza ilustracji, która pomaga czytelnikowi w dokonaniu wizualizacji omawianej zabawy. I tak, znajdziemy tutaj ilustracje zaczerpnięte z XIX-wiecznych czasopism, takich jak „Przyjaciel Dzieci”, „Świat Ilustrowany”, „Kłosy”, a także rysunki Daniela Chodowieckiego i Michała Stachowicza.

Na rozważania merytoryczne poparte ilustracjami składa się pięć części książki. Już na wstępie zostaje przedstawiona geneza owej publikacji. Czytelnik znajdzie tu bazę źródłową jej powstania. Książka zawiera opis 27 zabaw, z wyłączeniem zabaw słownych czy umysłowych, które zajmowały wolny czas dzieci na ziemiach polskich do XIX w. włącznie. Pedagogiczno-historyczny charakter publikacji zostaje dostrzeżony w znaczeniu zabawy nie tylko dla relaksu i odpoczynku, ale przede wszystkim dla prawidłowego rozwoju dziecka ${ }^{20}$. Charakterystyka wybranych zabaw, stanowiąca drugą część Dawnych zabaw dziecięcych, zawiera podział i opis zabaw na: zabawy małych dzieci, zabawy dziewczynek, zabawy chłopców, zabawy zręcznościowe, zabawy ruchowe oraz zabawy zimowe.

${ }^{20}$ D. Źołądź-Strzelczyk, K. Kabacińska (red.), Dawne zabawy dziecięce, Kielce - Warszawa 2008, s. 5. 
Tak jak dwie pierwsze części, umownie przyjmując, można skierować do starszego czytelnika, tak część trzecia z pewnością zadowoli nie tylko starszych, ale również młodszych odbiorców książki. Na blisko osiemdziesięciu ilustracjach zostały zobrazowane zabawy począwszy od zabaw z grzechotkami, na ślizganiu się w czasie zimy skończywszy. Każda ilustracja opatrzona pieczołowicie przygotowanym opisem, pozwala czytelnikowi odkryć na nowo szereg indywidualnych czy grupowych zabaw i dziecięcych swawoli. Dzięki źródłom ikonograficznym, które złożyły się na tę część publikacji, można dostrzec, jak kiedyś wyglądały współczesne zabawy, zobaczyć ich ewolucję na przestrzeni dziejów. Wiele z nich przetrwało do dziś dnia. Ujrzymy tutaj dziewczynki bawiące się „w dom”, chłopców na konikach z szablą w ręku, grę w kręgle, palanta, a nawet chodzenie na szczudłach czy puszczanie latawca. W obszarze gier ruchowych przeczytamy o dobrze znanej każdemu ciuciubabce, zabawie w chowanego, bieganiu, po czym po „paru kartkach” znajdziemy się z sankami w ręku, zjeżdżając z górki na przydomowym podwórku. Obszerną część publikacji wypełnioną ilustracjami i opisami gier zakończymy, rzucając się śnieżkami bądź też lepiąc bałwana.

Zamiast podsumowania, w publikacji znajdziemy kilka definicji związanych z problematyką zabawy, która jest atrybutem społeczeństwa ${ }^{21}$. Ryszard Kantor przywołuje tu takich znanych teoretyków zabawy, jak Rogera Caillois, który był zdania, że nie ma cywilizacji bez zabawy $i$ uczciwej gry ${ }^{22}$, Erika H. Eriksona, czy Jean Chateau. Przytacza fragment słynnego dzieła Listy o wychowaniu estetycznym historyka Fryderyka Schillera. Ponadto tę część Autor opatrzył poglądami Tadeusza Palecznego, Jana Grada, Bogusława Słukowskiego oraz Marii Przetacznik-Gierowskiej.

Książkę kończy rozdział pt. „Spędzanie czasu wolnego” autorstwa Jolanty Podsiadło, dyrektor Muzeum Zabawek i Zabawy w Kielcach. J. Podsiadło, koncentrując się na problematyce czasu wolnego, przedstawia po trosze zakres działania Muzeum Zabawek i Zabawy m.in. w oparciu o organizowane przez muzeum Europejskie Olimpiady Zabaw Dawnych i Zapomnianych. Zamysłem ich organizatorów jest - jak pisze Autorka przedstawienie zabawy jako działania wykonywanego dla własnej przyjemności, zjawiska opartego na udziale wyobraźni, tworzacego nowa rzeczywistośśc ${ }^{23}$.

Dawne zabawy dziecięce to pozycja skierowana do szerokiego grona odbiorców. Wszak, jak pisze Łukasz Gołębiowski, zabawa dotyczy każdego, szuka jej zarówno wiek dziecinny, średni i podeszły, nie odrzuca późna starość nawet; po trudach i pracy, rozrywa się nia w swobodniejszej chwili, kmiotek, mieszczanin, kupiec, szlachcic, pan możny, za nia się ubiega rycerz i prawnik, człowiek światowy $i$ kapłan lub zakonnik, uczony i prostak, płeć jedna i druga ${ }^{24}$.

21 Ibidem, s. 54.

${ }^{22}$ R. Caillois, Człowiek i sacrum, w thum. A. Tatarkiewicza i E. Nurskiej, Warszawa 1995, s. 186.

23 W. Okoń, Zabawa a rzeczywistość, Warszawa 1995, s. 44.

24 Ł. Gołębiowski, Gry i zabawy różnych stanów w kraju całym, lub niektórych tylko prowincjach: umieszczony tu kulig czyli szlichtada, ławy, maszkary, muzyka, tańce, reduty, zapusty, ognie sztuczne, rusałki, sobótki itp., Warszawa 1831. 
Redaktorki - Dorota Żołądź-Strzelczyk i Katarzyna Kabacińska - wydając Dawne zabawy dziecięce otwierają przed czytelnikiem wachlarz wspomnień i dziecięcej radości, skryty w opisach zabaw, w ilustracjach. Zabawa jest nieodzownym elementem życia każdego człowieka. Publikacja ta pozwala zrozumieć, że nawet w dobie społeczeństwa informacyjnego, komputer nie jest jedynym źródłem informacji dla dziecka. Nie musi być też on „wypychaczem” jego czasu wolnego. To właśnie zabawa jest dla dziecka źródłem poznania nowych wartości i informacji, przeniesienia się w świat iluzji i fikcji, czerpania przyjemności i radości z wykonywanych czynności, wreszcie, zaspokajania różnych potrzeb ludzkich. E. Hurlock wyróżnia cztery zasadnicze funcie zabawy: kształcącą, wychowawczą, terapeutyczną, projekcyjną ${ }^{25}$. Funkcja kształcąca wzbogaca wiedzę dziecka o otaczającym go świecie, kształtuje jego zmysły. Wychowawcza z kolei pozwala zaznajomić się jednostce z powszechnie obowiązującymi normami społecznymi i regułami postępowania. Funkcja terapeutyczna pomaga w wyrażaniu swoich uczuć, a projekcyjna pozwala wejść w różnorakie role społeczne. Jak stwierdza Ryszard Kantor $z a-$ bawy, ich opisy, analizy, stużyć moga do lepszego, petniejszego zrozumienia owej rzeczywistości, tym samym dla obserwatorów i badaczy stanowić moga znaczace źródło pozna$n i a^{26}$.

Wydawnictwo zostało opatrzone wskazówkami bibliograficznymi, dla tych którzy chcieliby poszerzyć swą wiedzę z zakresu omawianej w publikacji tematyki. Jest to również świadectwem obszernej znajomości tematyki Redaktorek, które przez Dawne zabawy dziecięce zachęcają do poszerzania wiedzy, dotyczącej dziecka na przestrzeni dziejów. Warto także zajrzeć do innych ich publikacji na ten temat - Doroty Żołądź-Strzelczyk Dziecko w dawnej Polsce, czy Katarzyny Kabacińskiej Zabawy i zabawki w osiemnastowiecznej Polsce. Lektura tekstu przekonuje, że Redaktorki potrafią przedstawić wspomniane wcześniej zagadnienia w formie przystępnej każdemu czytelnikowi, niezależnie od posiadanego, bądź też nie, stopnia naukowego. Recenzowana publikacja stanowi niezmiernie wartościową pozycję. Bogactwo informacji w niej zawartych, przyjmując formę not oraz ilustracji, zachęca do pogłębiania własnej wiedzy z omawianego zagadnienia.

25 E. Hurlock, Rozwój dziecka, Warszawa 1980.

${ }^{26}$ D. Źołądź-Strzelczyk, K. Kabacińska (red.), op.cit., s. 57. 